water surface temperatures between latitudes $39^{\circ}$ and $49^{\circ} \mathrm{N}$. and between longitudes $43^{\circ}$ and $56^{\circ} \mathrm{W}$. This information will facilitate the drawing of temperature curves which will be useful in locating the branches of the Labrador Current.

This year for the first time the United States Coast Guard cutters which undertake the patrol will use radar to locate icebergs at night and in fog. B-24 aircraft will also be employed to make air surveys of sea ice, growlers and icebergs. Both aircraft and cutters will be based on Argentia, Newfoundland, headquarters of the International Ice Patrol. Rear-Admiral Earl Griffith Rose, United States Coast Guard, has been appointed Commander of the North Atlantic Ice Patrol.

\title{
UNITED STATES ARCTIC METEOROLOGICAL STATIONS
}

[We print below the text of United States Public Law 296-70th Congress, Chapter $\downarrow$ 2nd Session. S. 765.]

$$
A N A C T
$$

Concerning the establishment of meteorological observation stations in the Arctic region of the Western Hemisphere, for the purpose of improving the weather forecasting service within the United States and on the civil international air transport routes from the United States.

Be it enacted by the Senate and House of Representatives of the United States of America in Congress assembled. That in order to improve the weather forecasting service of the United States and to promote safety and efficiency in civil air navigation to the highest possible degree, the Chief of the Weather Bureau, under the direction of the Secretary of Commerce, shall, in addition to his other functions and duties, take such action as may be necessary in the development of an international basic meteorological reporting network in the Arctic region of the Western Hemisphere, including the establishment, operation, and maintenance of such reporting stations in co-operation with the State Department and other United States governmental departments and agencies, with the meteorological services of foreign countries and with persons engaged in air commerce.

Sec. 2. There are hereby authorized to be appropriated such sums as may be necessary to carry out the provisions of this Act.

Approved February 12, 1946.

\section{SOVIET METEOROLOGICAL STATION ON VIZE ISLAND}

[Based on a note in Soviet News, No. 1292, 1 November 1945.]

In September 1945 Professors Tikhomirov and Goltsman of the Arctic Institute, with six others, established a meteorological station on Vize Island, which is situated midway between Franz Joseph Land and Severnaya Zemlya. The existence of this island was first suspected in 1924 by Professor Vladimir Vize 